\title{
Therapeutic Potential of Gene Transfer to Testis; Myth or Reality?
}

\author{
Yoshiyuki Kojima, Kentaro Mizuno, Yukihiro Umemoto, \\ Shoichi Sasaki, Yutaro Hayashi and Kenjiro Kohri \\ Department of Nephro-urology, Nagoya City University Graduate School \\ of Medical Sciences, Nagoya, \\ Japan
}

\section{Introduction}

Although there have been many reports about gene transfer to testicules, the original purpose is to develop more effective and simple methods to obtain transgenic animals than the most widely used method, which is the direct microinjection of foreign DNA into pronuclei of fertilized eggs. In the future, however, this technique has the potential to be the most useful approach for the treatment of testicular disorders such as male infertility and testicular cancer. In addition to whether gene transfer to testis is technically possible, the issues of social acceptance, ethics and safety must be addressed before it could become a clinical option. Germ cell gene therapy is rejected on the grounds that gene transfer to normal germ cells would be possible to affect future generations without precise understanding of the mechanism and control of gene expression. Therefore, at present, we should not make exceptions to the standing ethical rules in future clinical application of gene transfer to normal germ cells and consider appropriate gene therapy that avoids gene transfer to normal germ cells. On the other hand, the basic common consensus throughout the world is that gene transfer to somatic cells and cancer cells can be applied to treat wide range of disorders. Up to now, there has been no report about clinical application of gene transfer to testis. In this chapter, we discuss the current understanding of gene transfer to testes in animals, and the future possibility of clinical application of this technique for human testicular disorders.

\section{Normal function and anatomy of testis}

The testis has two primary functions: the production of sperm (spermatogenesis), which ensures the survival of our species, and the secretion of steroid hormones (steroidogenesis), which is necessary for male sexual differentiation, male secondary sexual functions, including behavior and spermatogenesis. Three main cells, germ cells (spermatogenic cells) and the somatic cells such as Sertoli cells and Leydig cells play a significant role in maintaining these testicular functions. Germ cells in the testis are composed of spermatogonia, spermatocytes and spermatids. Spermatogenesis can be divided into several processes, including the proliferation and differentiation of spermatogonia, which are stem cells, meiosis of spermatocytes, and their morphological changes to spermatids. Sertoli and 
Leydig cells support germ cell development, maturation and release into the seminiferous tubule lumen. The cell to cell crosstalk involves an intricate network of paracrine-autocrine systems that support endocrine input to modulate cell function (Saunders, 2003).

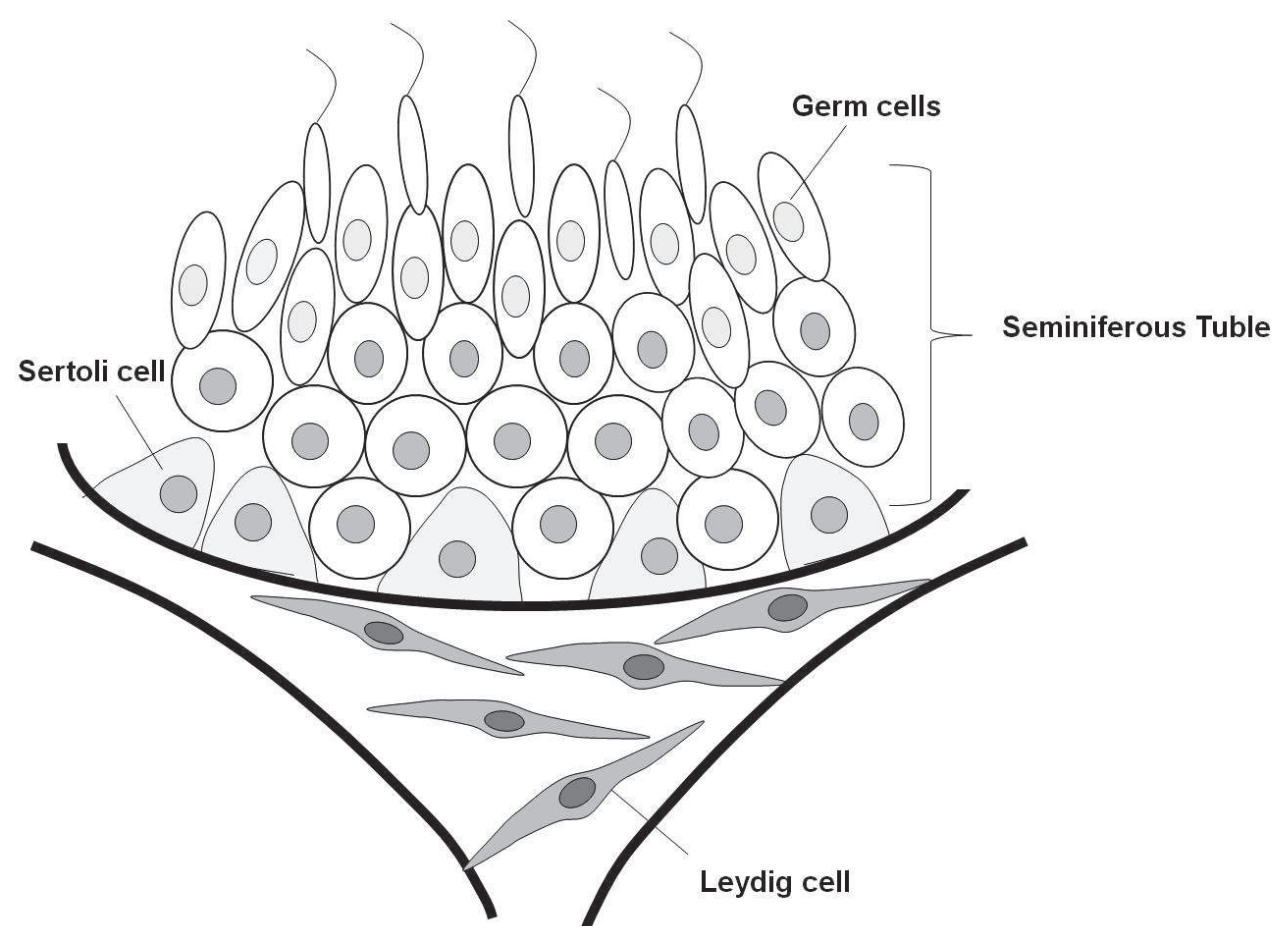

Fig. 1. Drawing of testis demonstrating relationships of seminiferous tubules and interstitium.

\section{Possible methods of gene transfer to testis-animal studes}

\subsection{In vivo gene transfer}

Establishment of the efficient methods of gene transfer to testis is important to apply for clinical use in the future. In animal studies, two methods, intratesticular injection and intratubular injection, can be used to perform gene transfer to the testis depending on the target cells. If the target cells are Leydig cells, intratesticular injection may be better, whereas if they are germ cells or Sertoli cells, intratubular injection may be preferable (Kojima, 2008a). These same basic methods will be used for humans.

\subsubsection{Intratesticular injection}

Intratesticular injection is a simpler method. DNA solution is injected directly into the testis through the scrotal skin using a needle and a disposable syringe. This technique allows the spread of DNA throughout the entire interstitial space of the testis, but not in the seminiferous tublues. 


\subsubsection{Intratubular injection}

For intratubular injection, two injection techniques are available, antegrade injection and retrograde injection. The testis is pulled out and exposed under a dissecting microscope in both techniques. Injection of DNA containing Trypan blue dye is useful way to monitor the accuracy of the testis injection.

\subsubsection{Antegrade injection}

For the antegrade injection, a small incision is made in the tunica, and then DNA solution is directly injected into the seminiferous tubules using an injection glass micropipette. Injection is usually made at several sites in the testis (Kojima, 2003).

\subsubsection{Retrograde injection}

For the retrograde injection, the injection glass micropipette is inserted into the rete testis via the efferent duct to allow direct injection into the seminiferous tubules. (Kurokawa, 2005). This technique enables the more thorough spread of exogenous DNA throughout the entire seminiferous tubule.

\subsection{Ex vivo gene transfer}

The testicular cell and tissue transplantation system with gene transfer is sometimes a useful procedure for gene transfer to the testis to produce transgenic animals. In this system, transduced donor testicular cells populations are transplanted by efferent duct injection into recipient animals (Nagano, 2001; Orwig, 2002) or transduced donor testicular tissues are transplanted directly into the testis.

\section{Vectors}

Generally, there are two main types of gene delivery vectors: non-viral and viral. Although several researchers have attempted gene transfer into animal testis using these vectors to produce transgenic animals, the choice of vector is one of the most important issues when applying for clinical trials of gene therapy for male infertility. Since these vectors have their own characteristics, they should be clarified before being used for testis-mediated gene transfer in vivo (Table 1). If a suitable vector could be developed, gene therapy could be considered safer than ICSI (Lamb, 2008).

\subsection{Non-viral vector}

It has been shown that non-viral vectors have several advantages over viral ones, as they are simple and cheap manufacture, no insert-size limitation, low immunogenicity and, as a result, a good safety profile. On the other hand, the disadvantages are the short duration of expression, inefficient transfection and difficulty in targeting transfection (Navarro, 2008). These techniques are so uncontrollable and unpredictable that they will not be appropriate for use in clinical trials in the short term, although some may be useful to produce transgenic animals. To apply for clinical use in the future, significant modification will be required.

\subsubsection{Naked DNA}

Sperm cells have the capacity to capture foreign DNA (Brackett, 1971). Several reports have demonstrated that sperm-mediated gene transfer in vitro, which is based on the intrinsic 


\begin{tabular}{|c|c|c|c|c|c|c|}
\hline & & \multirow[b]{2}{*}{ Expression periods } & \multicolumn{4}{|c|}{ Transgene Expression cells } \\
\hline & & & Germ cell & sperm & Sertoli cell & Leydig cell \\
\hline \multirow[t]{3}{*}{ Non-viral vector } & Naked DNA & NA & NA & + & NA & NA \\
\hline & Liposome & $<1$ week & - & + & - & - \\
\hline & Electroporation & $1-2$ months & + & + & + & + \\
\hline \multirow[t]{4}{*}{ Viral Vector } & Adenovirus & $>2$ months & - & - & + & + \\
\hline & Retrovirus & NA & + & NA & - & NA \\
\hline & Lentivirus & $>6$ months & - & - & + & NA \\
\hline & Baculovirus & NA & - & - & + & + \\
\hline
\end{tabular}

NA: not assessment

Table 1. Characteristics of vectors in testicular gene transfer system in vivo.

ability of sperm cells to bind and internalize exogenous DNA and to transfer it into the egg at fertilization, has succeeded in generating transgenic animals (Lavitrano, 1989, 1992, 1997, 2006; Francolini, 1993; Zani M, 1995).

On the other hand, Huguet E et al. (1998) analyzed the uptake of exogenous DNA by mouse and rat spermatozoa using in vivo methods. DNA was injected into the vas deferens, and spermatozoa were recovered $6 \mathrm{hr}$ later. Uptake of exogenous DNA occurred in $60-70 \%$ of spermatozoa after in vivo DNA injection into the proximal region of the vas deferens (Huguet, 1998). These male mice injected with exogenous DNA encoding green fluorescent protein (GFP) were mated with normal estrus females, and 7.5\% newborns were found positive by PCR for exogenous DNA. In these positive animals, some tissues showed GFP expression (Huguet, 2000).

\subsubsection{Liposome}

Cationic lipids interact with negatively charged nucleic acid molecules forming complexes in which the nucleic acid is coated by lipids (Felgner, 1987). The positive outer surface of the complex can associate with the negatively charged cell membrane, allowing the internalization of nucleic acid. In this technique, DNA is mixed with cationic lipid just before the addition of this complex to the testis. Several researchers have reported testismediated gene transfer using this method. As early as 3-4 days after microinjection of the exogenous gene mixed with cationic lipids into the seminiferous tubules, gene expression was observed within both immature and differentiated germ cells. By 40 days post-injection, the gene expression was restricted to the most immature germ cells in the basal portion of the seminiferous tubules (Celebi, 2002). Although transgene was transmitted to morula, blastocyst and mid-gestational fetuses, the ratio of animals carrying the exogenous gene decreased as they developed. Over $80 \%$ of morula-stage embryos expressed the exogenous gene, but only some postpartum progeny were foreign-DNA-positive with a high incidence of mosaicism (Yonezawa, 2001). Repeated injection with linearized plasmid DNA containing 
the $\beta$-galactosidase gene encapsulated with cationic liposome into the testis of adult mice via the scrotum resulted in the transmission of exogenous DNA sequences to blastocysts through fertilization (Ogawa, 1995). Sato et al. $(1999,2002)$ also attempted to transfect testicular spermatozoa with plasmid DNA by direct injection into testes to obtain transgenic animals. When injected males were mated with superovulated females 2 and 3 days after injection, more than $50 \%$ gene transmission was achieved in mid-gestational fetuses, and overt gene expression was not found in these fetuses. They suggested that plasmid DNA introduced into a testis is rapidly transported to the epididymis and then incorporated by epididymal spermatozoa.

\subsubsection{Electroporation}

Electroporation is a widely used technique for enhancing the efficiency of DNA delivery into cells. Application of electric pulses after local injection of DNA temporarily opens cell membranes and facilitates DNA uptake (De Vry, 2010). Electroporation provides more sperm cells to increase DNA uptake than unelectroporated spermatozoa (Gagné, 1991; Horan, 1992).

As a possible alternative and more effective method for generating transgenic mice, several researchers have attempted testis-mediated gene transfer using an in vivo electroporation method. After injection of exogenous DNA into the testis, the testes are held between a tweezer-type electrode, and square electric pulses are applied several times at 20-50 volts (Muramatsu, 1996, 1997; Yamazaki, 1998, 2000; Umemoto, 2002, 2005). Expression of the exogenous gene was clearly observed in germ cells of seminiferous tubules 48 hours after transfecting the mouse testis by in vivo electroporation (Muramatsu, 1997). Stable gene expression in spermatogenic cells using electroporation would be facilitated by retroviral integrase gene co-transfection (Ryoki, 2001). We also directly injected DNA, which was constructed as a cytomegalovirus enhancer/chicken $\beta$-actin promoter connected with the $\beta$ galactosidase gene (Umemoto, 2002, 2005), into mouse testes using a square-wave electroporator, and investigated the efficiency of gene transfer. The $\beta$-galactosidase activity was detected in germ cells and Sertoli cells in seminiferous tubules and in Leydig cells for 4 weeks (Umemoto, 2002, 2005); however, although electroporation is a simple and convenient technique for gene transfer to germ cells in the testis, the gene expression was deemed transient and uncontrollable (Umemoto, 2005). Another problem of electroporation is that the electric pulses themselves could result in testicular damage. In our previous reports, the Johnsen scores were significantly decreased and apoptotic cells were significantly increased in the testis several weeks after in vivo electroporation (Umemoto, 2002, 2005; Kojima, 2005). These results suggest that spermatogenic damage caused by electroporation itself could be important problems for clinical application.

Yomogida et al. (2002) investigated the rescue of spermatogenesis in Sl17H/ Sl17H mutant mice, which are infertile because of an altered stem cell factor (SCF), by gene transfer using electroporation. Dobashi et al. (2005) showed that the transfer of erythropoietin to rat testes by in vivo electroporation might reduce the risk of germ cell loss caused by surgically induced cryptorchidism. To define the transcriptional regulatory elements of the OAZt gene promoter, in vivo DNA transfer to mouse testes was performed using electroporation (Ike, 2004). RNA interference (RNAi) technology has become a novel tool for silencing gene expression in cells or organisms, and has also been used to develop new therapeutics for certain diseases. RNAi against endogenous Dmc1, which encodes a DNA recombinase that is expressed and functionally required in spermatocytes, was introduced into mouse testis 
by electroporation and led to the same phenotypes observed in null mutant mice (Shoji, 2005). Thus, an in vivo RNAi system using electroporation may provide a rapid means for assessing the physiological role of the spermatogenetic gene.

\subsection{Viral vector}

Viral vectors provide the most efficient transfection. Their main disadvantages concern limitations on the size of inserted DNA, difficulty of manufacture and possible immunogenicity (Navarro, 2008).

\subsubsection{Adenoviral vector}

Adenoviruses are the most commonly used gene-delivery vectors due to the efficiency of their in vivo gene transfer. This opinion is based upon their natural ability to infect a broad array of both dividing and terminally differentiated, nondividing cell types, their capacity to deliver large amounts of DNA, and the ease at which this vector platform can be mass produced (Appledorn, 2008). Furthermore, adenovirus vector remain the gene transfer vector of choice for numerous human clinical trials, as more clinical trials utilize Ad-based vectors than any other vector currently available.

Several researchers have attempted to perform adenovirus-mediated gene transfer to animal testis in vivo (Blanchard \& Boekelheide 1997; Kojima, 2003, 2008b; Takehashi, 2007). Intratesticular injection of adenoviral vector resulted in strong transgene expression in interstitial cells, including Leydig cells from seminiferous tubules (Kojima, 2003, Blanchard \& Boekelheide, 1997). By contrast, intratubular injection resulted in transgene expression along the seminiferous tubules, in which strong expression was observed in Sertoli cells. No transgene expression was detected in germ cells by either method (Kojima, 2003, Blanchard \& Boekelheide 1997).

Gene expression patterns by adenovirus-mediated gene transfer to the testis are particularly interesting and important from the viewpoint of gene therapy for male infertility in the future. Since it is not impossible to introduce a foreign gene precisely at specific chromosomal loci, abnormal sperm could be formed if a foreign gene is introduced into germ cells in the testis. This would increase the rate of offspring with anomalies; however, when an adenovirus vector is used, such problems can be avoided because of its biological characteristic of not introducing genes into germ cells in the testis. Fetuses and offspring produced by mating with males for several days after adenovirus-mediated gene transfer to the testis were normal and the number of neonates was not significantly different from that in the control group. None of the fetuses or offspring showed any abnormalities, and the transgene was not detected by RT-PCR and histochemical study (Kojima, 2003, 2008b). These results demonstrate that the risk of germline transmission following adenovirusmediated gene transfer to the testis is extremely low (Kojima, 2008b).

There are two problems concerning transfection with the adenoviral vector, i.e., cytotoxicity as a general biological characteristic and the immune response (Yang, 1994, 1995; Amin, 1995); however, although apoptosis was detected in some spermatocytes and a slight immune response was observed for a short period, it was temporary. The testis did not become highly atrophic, severe deterioration of the tubules was not detected, sperm motility was not lowered and sperm abnormalities were not observed (Kojima, 2003); therefore, transfection by adenoviral vector was not considered to have any adverse effects on spermatogenic function overall. Adenovirus-mediated gene transfer to the testis has several advantages and can be exploited for the treatment of male infertility in the future; however, 
to achieve a better therapeutic effect in the future, the different strategies of adenoviral improvement should be combined.

Some studies have reported the effect of gene transfer to an animal model testis on spermatogenesis using an adenoviral vector in vivo. Transfer of the tumor suppressor protein $p 53$ gene to rat seminiferous tubules by adenoviral vector using the retrograde technique impaired spermatogenesis (Fujisawa, 2001). On the other hand, adenovirus-mediated hepatocyte growth factor (HGF) gene transfer into the testis in cryptorchidism rats inhibited germ cell apoptosis and restored spermatogenesis (Goda, 2004). To explore the therapeutic usefulness of the HST-1/FGF-4 gene, which could be an important factor for spermatogenesis, in impaired spermatogenesis, adenovirus carrying the HST-1/FGF-4 gene was administered into the testis of mice after adriamycin treatment, and HST-1/FGF-4 gene transfer had a protective effect on experimentally induced testicular toxicity (Yamamoto, 2002).

\subsubsection{Retroviral vector}

Retroviral vectors based upon simple gammaretroviruses, complex lentiviruses, or potentially nonpathogenic spumaviruses represent relatively well-characterized tools that are widely used for stable gene transfer (Baum, 2006; Bushman 2007). They transfect by integrating the transgene into the target cell chromosome, but transgene expression ceases within days to weeks and tends to be shorter than adenovirus vectors. Unlike many other types of vectors currently being developed for gene therapy, retroviral vectors are able to genetically modify cells stably without perturbing cell growth (Kim, 2000). In the testis injected with retroviral vector into seminiferous tubules via rete testes, no cells with gene expression could be found (Ikawa, 2002); however, other researchers reported that retroviral vector was a powerful tool to transfer exogenous genes into the germ cell line and spermatogonia in vitro (Danno, 1999; De Miguel, 2003). Microinjection of a retroviral vector expressing the $\beta$-galactosidase gene into immature seminiferous tubules resulted in the direct transduction of spermatogonial stem cells, and the animals produced transgenic offspring after mating with females (Kanatsu-Shinohara, 2004).

\subsubsection{Lentiviral vector}

Lentviral vector are being increasingly used in basic and applied research. Human gene therapy clinical trials are currently underway using lentiviral vectors in a wide range of human diseases (Escors \& Breckpot 2010). The capacity to efficiently transduce nondividing cells, shuttle large genetic payloads, and maintain stable long-term transgene expression are attributes that have brought lentiviral vectors to the forefront of gene delivery vehicles for research and therapeutic applications in a clinical setting (Cockrell \& Kafri, 2007). Testes transduced with lentiviral vector expressed the trangene without impairing spermatogenesis. Expression patterns were characteristic of Sertoli cells and gene expression was observed over a period of 6 months (Ikawa, 2002). Although spermatogenesis can be restored in $S l / S l^{d}$ mutant mice by transducing Sertoli cells with lentiviral vectors generating a functional $c$ - $k$ it ligand, KL2, an insufficient number of spermatozoa for IVF were collected. Sperm collected from recipient testes were able to produce normal pups after intracytoplasmic sperm injection. None of the offspring carried the transgene, suggesting the inability of lentiviral vectors to infect spermatogenic cells in vivo (Ikawa, 2002). 


\subsubsection{Baculoviral vector}

Since the discovery that baculoviruses can efficiently transduce mammalian cells, baculoviruses have been extensively studied as potential vectors for both in vitro and in vivo gene therapy $(\mathrm{Hu}, 2008)$. Baculovirus-mediated gene transfer is simple to perform, reproducible, and demonstrates no overt cell toxicity, and is particularly useful for repetitive or moderately high-throughput procedures, such as cell-based assays, or for situations where transfection procedures are inadequate (Merrihew, 2004; Kost, 2005). Baculovirusmediated gene transfer to the testis via intratubular injection resulted in the gene expression in Sertoli cells but not in spermatocytes or sperm (Tani, 2003]. Park et al. (2009) demonstrated that intra-tunica albuguineal injection of GFP-baculovirus into the mouse testis resulted in a high level of GFP expression in the interstitial tissues. In addition, intratunica albuguineal injection of a modified baculovirus that encoded recombinant rat insulinlike growth factor binding protein (IGFBP)-5 resulted in an increase in IGFBP-5 in testis and semen.

\section{Future prospects of gene therapy for male infertility}

\subsection{Abnormal sperm production and male infertility}

Normal fertility is defined as achieving a pregnancy within one year by regular coital exposure. On the other hand, infertility is defined as the inability to conceive after one year of unprotected intercourse, which affects approximately $15 \%$ of couples trying to conceive in western countries. Worldwide more than 70 million couples suffer from infertility (Ombelet, 2008). It is generally reported that in approximately $30 \%$ of cases, infertility is mainly due to a male factor, and 70 to $90 \%$ of male infertility arises from impaired spermatogenesis with the clinical presentation of abnormal sperm production, such as oligozoospermia and azoospermia (Greenberg, 1978). The presented cases of male infertility include varicocele, cryptorchidism, obstruction of spermatic ducts, and endocrine disorders; however, most cases continue to be labeled with the diagnosis of "idiopathic infertility" or given descriptive diagnoses that do not provide a cause for their defect, although basic research helps to define the associated genes and the mechanisms responsible for the development, function and regulation of spermatogenesis (Matzuk \& Lamb, 2008).

\subsection{Present therapeutic options of male infertility and its limitation}

Evolving therapies have allowed the use of sperm from men with compromised spermatogenesis, obstructive azoospermia, and sperm functional deficiency, enabling these men to procreate when unable to do so naturally (Oates, 2008). Assisted reproductive technology (ART) is the most appropriate management if a natural pregnancy fails to occur, and this is increasingly used in the treatment of both male and female infertility. Recently, severe male infertility, such as azoospermia, has been treated successfully by intracytoplasmic sperm injection (ICSI) (Palemo, 1992, 1996). Sperm can be obtained by microepididymal sperm aspiration (MESA), percutaneous sperm aspiration (PESA), and testicular sperm extraction (TESE) from patients with male infertility. ICSI involves the injection of a single sperm directly into the cytoplasm of a mature egg (oocyte) using a glass needle (pipette). ICSI guarantees high fertilization rates and could also theoretically lead to higher implantation rates. Fertilization rates were in the range of $60-90 \%$ and the delivery rate per retrieval was $38.5 \%$ in the first 560 couples (Palermo, 1996). Although ICSI allows otherwise sterile couples to become parents, there is still only an incomplete picture of the 
risks associated with the usage of these ART to offspring (Staessen, 1999; Alukal \& Lamb, 2008). Several data have indicated a higher risk of congenital malformation (Sutcliffe, 2001; Hansen M, 2002), chromosome aneuploidy (In't Veld P, 1995; Liebaers, 1995; Loft A, 1999), low birth weight (Schieve, 2002), and imprinting defects such as Angelman syndrome (Cox, 2002) for children conceived by ICSI than for children conceived naturally. Additionally, this technique is not a cure per se for male infertility patients. The empirical treatments used in the past for male infertility patients are probably ineffective, and no effective treatments have been proved to improve spermatogenesis in idiopathic male infertility despite major advances in ART; therefore, additional prospective treatments for male infertility patients are needed to achieve paternity potential.

\subsection{Therapeutic potential of gene transfer to tesits for male infertility}

Fertilization is better in vivo than in vitro for male infertility. Clinically, testicular gene therapy may be useful to treat male infertility in the future because it is possible to promote spermatogenesis in male infertility patients diagnosed with pathological hypospermatogenesis, maturation arrest or Sertoli cells only. Since testicular cells play a significant role in creating life and personality, it is very important to understand the safety issues and to control the expression of transferred genes (Kojima, 2006a). Numerous difficult hurdles remain to be overcome in the clinical application of gene transfer to testis under the present conditions.

\subsubsection{Appropriate methods and vectors of future gene therapy for male infertility}

The basic common consensus throughout the world is that somatic gene therapy can be applied to treat a wide range of disorders, including cancer and inherited disease (Smith, 2003). The ethical issues in somatic gene therapy are primarily concerned with the risk of this procedure, such as vector toxicity and oncogenesis. On the other hand, although germline gene therapy is theoretically possible, it is rejected on the grounds that it would be possible to affect future generations without precise understanding about the mechanism and control of gene expression [(Kojima, 2006a). At present, we should not make exceptions to the standing ethical rules in future gene therapy for male infertility and consider appropriate gene therapy that avoids gene transfer to germ cells.

Within the seminiferous epithelium of seminiferous tubules, spermatogenesis occurs on the surface of Sertoli cells. In other words, Sertoli cells directly support spermatogenesis. They are involved in metabolic exchange with germ cells, as well as in their nutrition and the secretion of tubular fluid into the luminal compartment and the exclusive targets of folliclestimulating hormone (FSH), androgens and other hormones within the testis (Brehm \& Steger, 2005). On the other hand, Leydig cells are the main source of the androgen hormone, testosterone, which is located in the interstitial space, outside the seminiferous tubules. This function is regulated by luteinizing hormone (LH), paracrine factors secreted by cells within the seminiferous tubules and autoregulatory factors.

Disruption of spermatogenesis, which results in male infertility, can therefore be caused by defects affecting the germ cells or Sertoli cells or sometimes Leydig cell dysfunction. Germ cells are appropriate target cells of gene transfer into the testis to generate transgenic animals, while Sertoli cells and Leydig cells may be appropriate target cells for the clinical application of male infertility treatment on the basis of ethical issues. Viewed from this point, adenoviral-, lentiviral- or baculoviral-mediated gene transfer may be effective for 
transfecting testicular somatic cells, Sertoli cells or Leydig cells, because they can not introduce exogenous genes into germ cells, and are applicable vectors for in vivo gene therapy for male infertility in the future (Kojima, 2008a). Adenoviral vectors may currently be the most appropriate candidate to use in future clinical application because there is sufficient information from clinical trials about several other diseases.

Intratubular injection (antegrade injection or retrograde injection) is a useful technique to introduce genes into Sertoli cells, while intratesticular injection may be useful for Leydig cells.

It is important to choose an appropriate vector for clinical use. The disadvantage of liposome and electroporation methods for clinical application was that they showed potential for gene expression in germ cells and strong adverse effects on spermatogenesis. On the other hand, adenovirus-mediated gene transfer may be a more effective and superior method for transfecting testicular cells among these three methods and may be more applicable for gene therapy for male infertility in the future (Kojima, 2005).

\subsubsection{Candidate genes of future gene therapy for male infertility}

Spermatogenesis is a complex program of differentiation that takes place within the testicular seminiferous tubules, which are composed of germ cells and somatic Sertoli cells (Brehm \& Steger, 2005; Bergmann 2005). Two control mechanisms are involved in the regulation of spermatogenesis; hormone and genetics. Sertoli cells trigger germ cell development by not only mediating hormonal stimuli of FSH and androgen secreted by Leydig cells, but also numerous genes. Understanding the mechanisms by which genes and gene products are expressed or repressed in the testes enables the development of strategies to treat male infertility. A lot of candidate male fertility-associated genes have been revealed from knockout mice phenotypes (Cram, 2001, O'Bryan MK \& de Kretser, 2006). It is important to perform detailed phenotypic analysis in order to extract the maximum amount of information from each model; however, despite the identification of an increasing number of candidate genes involved in spermatogenesis, the range of diagnostic genetic tests for male infertility remains extremely limited (Nuti \& Krausz, 2008). Normal spermatogenesis and fertility are dependent upon paracrine or autocrine interactions between somatic cells (Sertoli and Leydig cells) and germ cells, and upon endocrine support from the pituitary gland (Saunders, 2003).

Several possible genes may be essential for Sertoli and Leydig cell function to support normal spermatogenesis. Testicular gene therapy for these cells as target cells may be useful to treat male infertility in the future, especially for those who have no spermatozoa in their testes at all, such as pathological maturation arrest or Sertoli cells only. From our viewpoint, Sertoli cells are more appropriate target cells, because they perform crucial functions that initiate, promote and maintain spermatogenesis directly in seminiferous tubules.

Disorders of testicular function may originate as a result of abnormal development or proliferation of Sertoli cells (Sharpe, 2003). Idiopathic male infertility, including pathologically maturation arrest and Sertoli cell-only syndrome, may result in abnormal Sertoli cell function, which disrupts the normal progression of spermatogenesis [Kojima et al. 2006c].

Marker genes of maturity and immaturity of Sertoli cells include anti-Müllerian hormone, vimentin, connexin 26, connexin 43, aromatase, cytokeratin-18, GATA1, laminin $\alpha 5$, M2A antigen, p27kip1, inhibin $\alpha$, sulphated glycoprotein 2, androgen receptor and WT-1 (Brehm \& 
Steger, 2005; Sharpe, 2003). In addition, alterations of transcription regulation in the testis may cause idiopathic male infertility. Transcription factors include CREB, Sox3, Pem (Rhox5) and DAX1, which are essential for spermatogenesis and are expressed not in germ cells but in Sertoli cells of seminiferous tubules (Hummler, 1994; Yu, 1998; Weiss, 2003; Maclean, 2005a,b; Kojima, 2006c). Clarifying the role of these factors in spermatogenesis may advance the clinical application of gene therapy for patients with male infertility.

On the other hand, Leydig cells may also be target cells of gene therapy. Hypotheses about the underlying mechanism of the depletion of germ cells in Klinefelter syndrome males, which is the most common sex chromosome abnormality and the most frequent genetic cause of male infertility, include Leydig cell insufficiency and disturbed apoptosis regulation of Leydig cells (Aksglaede, 2006). There is also evidence of Leydig cell impairment in a proportion of men treated with cytotoxic chemotherapy for malignant disease (Howell, 2001). Endocrine disruptors can disrupt not only spermatogenesis but also normal endocrine function of Leydig cells, acting directly on Leydig cells to diminish testosterone production by interfering with the expression of specific genes in the steroidogenic pathway (Skakkebaek, 2001). Marker genes, including P450(CYP) steroid hydroxylase, 3ß-HSD [143], Androgen receptor [144], LHR [145], Ad4BP/SF-1 [134,146,147] are expressed in Leydig cells (Weiss, 1992, Morohashi, 1993, 1994; Luo, 1994; Xu, 2007; Kojima, 2006c,], which are implicated in steroidogenesis or spermatogenesis. They may also be candidate genes for gene therapy in the future.
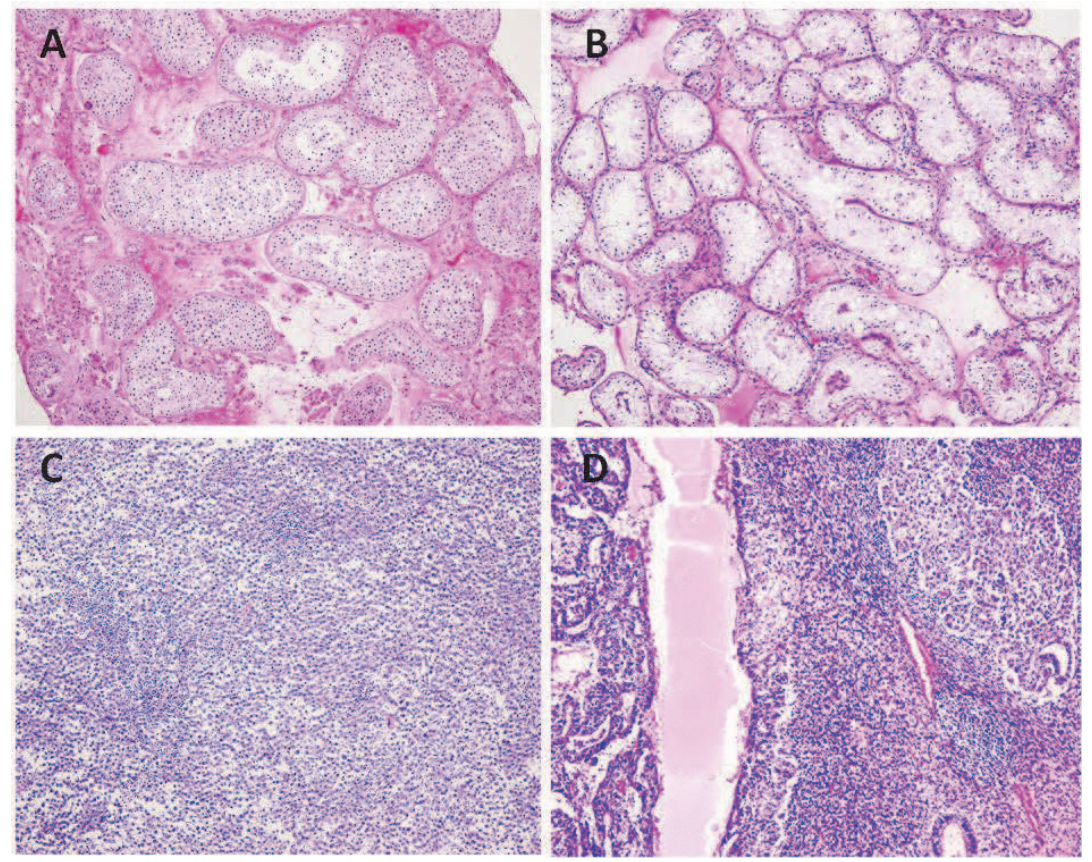

Fig. 2. Histological findings of normal spermatogenesis (A), male infertility, (Sertoli-cell only) (B) and testicular cancer; seminoma (C) and non-seminoma (embryonal carcinoma and teratoma) (D). 


\section{Future prospects of gene therapy for testicular cancer}

\subsection{Testicular cancer and germ cell tumor}

Testicular cancer is the most frequent solid tumor in young male adults and a disease with elusive pathogenesis. Germ cell tumors (GCTs) represent $95 \%$ of all testicular cancers (Diamantopoulos, 2010). Testicular cancer represents the most curable solid tumor, with a 10-year survival rate of more than 95\% (Travis, 2010). Especially, clinical stage I testicular cancer is highly curable. Since treatment for testicular cancer directly affects gonadal tissues, fertility rate after treatment for testicular cancer is reduced.

GCTs are divided into two broad group, seminnoma and non-seminoma. Seminoma retains the morphology of spermatogonial GCs. On the other hand, non-seminoma display embryonal and extra-embryonal differentiation patterns which include primitive zygotic (embryonal carcinoma), embryonal-like somatically differentiated (teratoma), and embryonally differentiated (choriocarcinoma and yolk-sac tumor) phenotypes (Chaganti \& Houldsworth 2000).

\subsection{Present therapeutic options of testicular cancer and its limitation}

Treatment strategy is chosen according to the patient stage and prognostic group stratification. The standard therapy is generally considered to be radical orchiectomy even for bilateral testis cancer; however, partial orchiectomy should be undertaken only in selected patients -men with bilateral testicular cancer or GCTs in a solitary testis-if the size and location of the mass are amenable to surgery. Partial orchiectomy provides potential benefits over radical surgery by reducing the need for androgen substitution, lessening psychological stress, and preserving fertility, with a durable cure rate. However, partial orchiectomy is not always appropriate according to tumor size. Although alternative strategies of organ preservation, such as radiotherapy and chemotherapy, might be appropriate treatment options in the future, the safety and efficacy of these procedures have not been demonstrated in larger and prospective studies with longer follow-up (Zuniga, 2010). Therefore, gene therapy may be one of the options for testicular cancer in the future.

\subsection{Therapeutic potential of gene transfer to tesits for testicular cancer}

Several preclinical studies have demonstrated that gene therapy produced antitumor effects, suggesting its feasibility in clinical settings. Actual trials of gene therapy for certain cancers have already been reported; however, to our knowledge, there is no report about gene therapy for GCTs, because of complexity of its pathogenesis. Therefore, which method or vector is useful for clinical application has remained unknown.

A lot of researchers have attempted to identify the candidate genes of GCTs. Cytogenetic and molecular genetic analysis of GCTs has yielded important data relevant to the understanding of the mechanism of GC transformation (Chaganti \& Houldsworth, 2000). Virtually $100 \%$ of tumors show increased copy number of the short arm of chromosome 12 (12p), as one or more copies of isochoromosome of $12 p$ or as tandem duplications of $12 p$, in situ or transposed elsewhere in the genome. This observation enhanced our understanding of the underlying genetic etiology of the disease because of its invariant presence (Houldsworth, 2006). Because the entire 12p, comprising about 400 genes, is involved, this would suggest that at least two, if not more, physically distant loci are the targets of the abnormality. In this region, there are several candidates with functions consistent with roles in cell growth, including CCND2, GLUT3, GAPDH, TPI1 NANOG, DPPA3 and GDF3. It is 
clear that gain of $12 p$ is multifunctional with respect to biologic processes affected, which in this unique tumor system are inextricably linked; transformation and maintenance of pluripotency (Houldsworth, 2006). Epigenetic approach can also provide new knowledge about pathogenesis of GCTs. Aberrant promoter hypermethylation has been reported for several genes (PRSS21, MGMT, RASSF1A) in GCTs, suggestive of roles in GC transformation (Houldsworth, 2006).

Stem cell research has provided new insights on pathogenesis of GCTs. Cancer stem cells may be target for cancer cells (Hombach-Klonisch, 2008). It is becoming increasingly evidence that cancer constitutes a group of diseases involving altered stem cell maturation/differentiation and the disturbance of regenerative process. Previous study showed a substantial overlap in the expression patterns of testicular embryonal carcinomas and embryonic stem (ES) cells. Several candidate genes including Oct3/4, SOX2, CENPA and $P O D X L$, which may contribute to the maintenance of plutipotency, have recently been detected. They may also be candidate genes for gene therapy in the future

\section{Conclusions}

Our limited understanding of the complex regulatory mechanisms underlying normal spermatogenesis and pathogenesis of GCTs makes it difficult to identify specific target genes for gene therapy for male infertility and GCTs. Recent remarkable advance in molecular approaches have contributed to find candidate genes and provided new knowledge on molecular genetics of testicular disorders including male infertility and GCTs. Although more genetic information about the molecular basis of spermatogenesis, male infertility and GCTs will be needed to apply gene therapy for male infertility and GCTs patients, these information will lead to new strategies for the clinical management and gene therapy will provides great benefits for the patients with these testicular diseases in the near future.

\section{References}

Aksglaede L, Wikström AM, Rajpert-De Meyts E, Dunkel L, Skakkebaek NE, Juul A. (2006) Natural history of seminiferous tubule degeneration in Klinefelter syndrome.Hum Reprod Update 12:39-48.

Alukal JP, Lamb DJ. Intracytoplasmic sperm injection (ICSI)--what are the risks? (2008) Urol Clin North Am. 35:277-288.

Amin R, Wilmott R, Schwarz Y, Trapnell B, Stark J (1995) Replication-deficient adenovirus induces expression of interleukin- 8 by airway epithelial cells in vitro. Hum Gene Ther. 6:145-153.

Appledorn DM, Seregin S, Amalfitano A. (2008) Adenovirus vectors for renal-targeted gene delivery. Contrib Nephrol. 159:47-62.

Baum C, Schambach A, Bohne J, Galla M. Retrovirus vectors: toward the plentivirus? (2006) Mol Ther 13:1050-1063.

Bergmann M (2005) Spermatogenesis--physiology and pathophysiology Urologe A. 44:11311132.

Blanchard KT, Boekelheide K (1997) Adenovirus-mediated gene transfer to rat testis in vivo.Biol Reprod 56:495-500. 
Brackett BG, Baranska W, Sawicki W, Koprowski H. (1971) Uptake of heterologous genome by mammalian spermatozoa and its transfer to ova through fertilization.Proc Natl Acad Sci U S A 68:353-357.

Brehm R, Steger K. (2005) Regulation of Sertoli cell and germ cell differentation. Adv Anat Embryol Cell Biol 181:1-93.

Bushman FD (2007) Retroviral integration and human gene therapy. J Clin Invest 117:20832086.

Celebi C, Auvray P, Benvegnu T, Plusquellec D, Jégou B, Guillaudeux T (2002) Transient transmission of a transgene in mouse offspring following in vivo transfection of male germ cells. Mol Reprod Dev 62: 477-482.

Chaganti RS, Houldsworth J (2000) Genetics and biology of adult human male germ cell tumors. Cancer Res. 60:1475-82

Cockrell AS, Kafri T (2007) Gene delivery by lentivirus vectors. Mol Biotechnol. 36:184-204.

Cox GF, Burger J, Lip V Mau UA, Sperling K, Wu BL, Horsthemke B (2002) Intracytoplasmic sperm injection may increase the risk of imprinting defects. Am J Hum Genet 71:162-16

Cram DS, O'Bryan MK, de Kretser DM (2001) Male infertility genetics--the future. J Androl 22:738-746.

Danno S, Itoh K, Baum C (1999) Efficient gene transfer by hybrid retroviral vectors to murine spermatogenic cells. Hum Gene Ther 10:1819-1831.

De Miguel MP, Donovan PJ. Determinants of retroviral-mediated gene delivery to mouse spermatogonia. Biol Reprod 2003; 68:860-866.

De Vry J, Martínez-Martínez P, Losen M, Temel Y, Steckler T, Steinbusch HW, De Baets MH, Prickaerts J (2010) In vivo electroporation of the central nervous system: a non-viral approach for targeted gene delivery. Prog Neurobiol. 92:227-44.

Diamantopoulos N, Kortsaris A (2010). Testicular germ cell tumors. J BUON. 15:421-34.

Dobashi M, Goda K, Maruyama H, Fujisawa M (2005) Erythropoietin gene transfer into rat testes by in vivo electropo-ration may reduce the risk of germ cell loss caused by cryptorchidism. Asian J Androl 7:369-373.

Escors D, Breckpot K. Lentiviral vectors in gene therapy: their current status and future potential (2010). Arch Immunol Ther Exp (Warsz). 58(2):107-19.

Felgner PL, Gadek TR, Holm M (1987) Lipofection: a highly efficient, lipid-mediated DNAtransfection procedure. Proc Natl Acad Sci U S A 84:7413-7417.

Francolini M, Lavitrano M, Lamia CL (1993) Evidence for nuclear internalization of exogenous DNA into mammalian sperm cells. Mol Reprod Dev 34:133-139.

Fujisawa M, Shirakawa T, Fujioka H (2001) Adenovirus-mediated p53 gene transfer to rat testis impairs spermatogenesis. Arch Androl 46:223-231.

Gagné MB, Pothier F, Sirard MA (1991) Electroporation of bovine spermatozoa to carry foreign DNA in oocytes. Mol Reprod Dev 29:6-15.

Goda K, Fujisawa M, Shirakawa T (2004) Adenoviral-mediated HGF expression inhibits germ cell apoptosis in rats with cryptorchidism. J Gene Med 6:869-876.

Goldstein M, Tanrikut C (2006). Microsurgical management of male infertility. Nat Clin Pract Urol 3:381-391.

Greenberg SH, Lipshultz LI, Wein AJ (1978) Experience with 425 subfertile male patients. J Urol 119:507-510.

Hansen M, Kurinczuk JJ, Bower C, Webb S (2002) The risk of major birth defects after intracytoplasmic sperm injection and in vitro fertilization. N Engl J Med 346:725730 . 
Hombach-Klonisch S, Paranjothy T, Wiechec E, Pocar P, Mustafa T, Seifert A, Zahl C, Gerlach KL, Biermann K, Steger K, Hoang-Vu C, Schulze-Osthoff K, Los M (2008) Cancer stem cells as targets for cancer therapy: selected cancers as examples. Arch Immunol Ther Exp (Warsz). 56:165-80.

Horan R, Powell R, Bird JM, Gannon F, Houghton JA (1992) Effects of electropermeabilization on the association of foreign DNA with pig sperm.Arch Androl 28:105-114.

Houldsworth J, Korkola JE, Bosl GJ, Chaganti RS (2006). Biology and genetics of adult male germ cell tumors. J Clin Oncol. 24:5512-8.

Howell SJ, Shalet SM (2001) Testicular function following chemotherapy. Hum Reprod Update. 7:363-369.

$\mathrm{Hu}$ YC (2008) Baculoviral vectors for gene delivery: a review. Curr Gene Ther. 8:54-65.

Huguet E, Esponda P (1998). Foreign DNA introduced into the vas deferens is gained by mammalian spermatozoa. Mol Reprod Dev 51:42-52.

Huguet E, Esponda P (2000) Generation of genetically modified mice by spermatozoa transfection in vivo: preliminary results.Mol Reprod Dev 56:243-7.

Hummler E, Cole TJ, Blendy JA (1994) Targeted mutation of the CREB gene: compensation within the CREB/ATF family of transcription factors. Proc Natl Acad Sci U S A 91:5647-5651.

Ikawa M, Tergaonkar V, Ogura A, Ogonuki N, Inoue K, Verma IM (2002) Restoration of spermatogenesis by lentiviral gene transfer: offspring from infertile mice. Proc Natl Acad Sci U S A 99:7524-7529.

Ike A, Ohta H, Onishi M, Iguchi N, Nishimune Y, Nozaki M (2004) Transient expression analysis of the mouse ornithine decarboxylase antizyme haploid-specific promoter using in vivo electroporation. FEBS Lett 559:159-164.

In't Veld P, Branderburg H, Verhoeff A, Dhont M, Los F (1995) Sex chromosomal anomalies and intracytoplasmic sperm injection. Lancet 346:773

Kanatsu-Shinohara M, Toyokuni S, Shinohara T (2004)Transgenic mice produced by retroviral transduction of male germ line stem cells in vivo. Biol Reprod 71:12021207.

Kim SH, Kim S, Robbins PD (2006) Retroviral vectors. Adv Virus Res. 2000;55:545-563.

Kim SY. Assessing and communicating the risks and benefits of gene transfer clinical trials. Curr Opin Mol Ther. 8:384-389.

Kojima Y, Sasaki S, Umemoto Y, Hashimoto Y, Hayashi Y, Kohri K. (2003) Effects of adenovirus mediated gene transfer to mouse testis in vivo on spermatogenesis and next generation. J Urol 170:2109-2114.

Kojima Y, Sasaki S, Umemoto Y, Hashimoto Y, Hayashi Y, Kohri K (2005) Comparison of characteristics of several vectors to testicular gene transfer system. J Urol 173 (Suppl):407-408.

Kojima Y., Sasaki S, Kohri K (2006a) Therapeutic options: Current research and future prospects for gene therapy in andrology. In: Eds Hargreave T, Comhaire F and Schill W-B. Andrology for clinician. Heiderberg, Springer; pp592-598.

Kojima Y, Sasaki S, Hayashi Y, Umemoto Y, Morohashi K, Kohri K (2006b). Role of transcription factors Ad4BP/SF-1 and DAX-1 in steroidogenesis and spermatogenesis in human testicular development and idiopathic azoospermia. Int J Urol 13:785-793.

Kojima Y, Kurokawa S, Mizuno K, Umemoto Y, Sasaki S, Hayashi Y, Kohri K (2008a) Gene transfer to sperm and testis: future prospects of gene therapy for male infertility. Curr Gene Ther. 8:121-34 
Kojima Y, Hayashi Y, Kurokawa S, Mizuno K, Sasaki S, Kohri K (2008b) No evidence of germ-line transmission by adenovirus-mediated gene transfer to mouse testes. Fertil Steril. 89:1448-1454.

Kost TA, Condreay JP, Jarvis DL (2005) Baculovirus as versatile vectors for protein expression in insect and mammalian cells. Nat Biotechnol 23:567-575.

Kuhlmann KF, Gouma DJ, Wesseling JG (2008) Adenoviral gene therapy for pancreatic cancer: where do we stand? Dig Surg. 25:278-292

Kurokawa S, Kojima Y, Mizuno K, Nakane A, Hayashi Y, Kohri K (2005) Effect of epidermal growth factor on spermatogenesis in the cryptorchid rat. J Urol. 174:2415-2419.

Lamb DJ. Would gene therapy for the treatment of male infertility be safe? (2008) Nat Clin Pract Urol. 5:594-595.

Lavitrano M, Camaioni A, Fazio VM, Dolci S, Farace MG, Spadafora C (1989) Sperm cells as vectors for introducing foreign DNA into eggs: genetic transformation of mice. Cell 57:717-723.

Lavitrano M, French D, Zani M, Frati L, Spadafora C (1992) The interaction between exogenous DNA and sperm cells. Mol Reprod Dev 31:161-169.

Lavitrano M, Maione B, Forte E (1997) The interaction of sperm cells with exogenous DNA: a role of CD4 and major histocompatibility complex class II molecules. Exp Cell Res 233:56-62.

Lavitrano M, Busnelli M, Cerrito MG, Giovannoni R, Manzini S, Vargiolu A. (2006) Spermmediated gene transfer. Reprod Fertil Dev 18:19-23.

Liebaers I, Bonduelle M, Van Assche E, Devroey P, Van Steirteghem A (1995) Sex chromosome abnormalities after intracytoplasmic sperm injection. Lancet 346:1095

Loft A, Petersen K, Erb K Mikkelsen AL, Grinsted J, Hald F, Hindkjaer J, Nielsen KM, Lundstrom P, Gabrielsen A, Lenz S, Hornnes P, Ziebe S, Ejdrup HB, Lindhard A, Zhou Y, Nyboe Andersen A (1999) Danish cohort of 730 infants born after intracytoplasmic sperm injection (ICSI) 1994-1997. Hum Reprod 14:2143-2148

Luo X, Ikeda Y, Parker KL (1994) A cell-specific nuclear receptor is essential for adrenal and gonadal development and sexual differentiation. Cell 77: 1994;481-90.

Matzuk MM, Lamb DJ (2008) The biology of infertility: research advances and clinical challenges. Nat Med. 14:1197-1213.

Maclean JA 2nd, Wilkinson MF. Gene regulation in spermatogenesis (2005a) Curr Top Dev Biol 71:131-197.

Maclean JA 2nd, Chen MA, Wayne CM (2005b) Rhox: a new homeobox gene cluster. Cell 120:369-382.

Merrihew RV, Kost TA, Condreay JP (2004) Baculovirus-mediated gene delivery into mammalian cells.Methods. Mol Biol 246:355-365.

Morohashi K, Zanger UM, Honda S, Hara M, Waterman MR, Omura T (1993) Activation of CYP11A and CYP11B gene promoters by the steroidogenic cell-specific transcription factor, Ad4BP. Mol. Endocrinol 7: 1196-204.

Morohashi K, Omura T (1994) Ad4BP/SF-1, a transcription factor essential for the transcription of steroidogenic cytochrome P450 genes and for the establishment of the reproductive function. FASEB J 10: 1569-77.

Muramatsu T, Shibata O, Ohmori Y, Okumura J (1996) In vivo electroporation: A convenient method for gene transfer to testicular cells in mice. Anim Sci Technol 67:975-982.

Muramatsu T, Shibata O, Ryoki S, Ohmori Y, Okumura J (1997) Foreign gene expression in the mouse testis by localized in vivo gene transfer. Biochem Biophys Res Commun 233:45-49. 
Nagano M, Brinster CJ, Orwig KE, Ryu BY, Avarbock MR, Brinster RL (2001) Transgenic mice produced by retroviral transduction of male germ-line stem cells.Proc Natl Acad Sci U S A 98:13090-13095.

Navarro J, Risco R, Toschi M, Schattman G (2008) Gene therapy and intracytoplasmatic sperm injection (ICSI) - a review. Placenta. 29:193-199.

Nuti F, Krausz C (2008) Gene polymorphisms/mutations relevant to abnormal spermatogenesis. Reprod Biomed Online. 2008;16:504-513

Oates RD. The genetic basis of male reproductive failure. Urol Clin North Am.35:257-70

O'Bryan MK, de Kretser D (2006) Mouse models for genes involved in impaired spermatogenesis. Int J Androl 29:76-89.

Ogawa S, Hayashi K, Tada N, Sato M, Kurihara T, Iwaya M (1995) Gene expression in blastocysts following direct injection of DNA into testis. J Reprod Dev 41: 379-382.

Ombelet W, Cooke I, Dyer S, Serour G, Devroey P (2008) Infertility and the provision of infertility medical services in developing countries. Hum Reprod Update. 14:605-621

Orwig KE, Avarbock MR, Brinster RL (2002) Retrovirus-mediated modification of male germline stem cells in rats.Biol Reprod 67:874-879.

Palermo G, Joris H, Devroey P, Van Steirteghem AC (1992) Pregnancies after intracytoplasmic injection of single spermatozoon into an oocyte. Lancet. 340:17-18.

Palermo GD, Cohen J, Rosenwaks Z (1996). Intracytoplasmic sperm injection: a powerful tool to overcome fertilization failure. Fertil Steril 65:899-908.

Park HJ, Lee WY, Kim JH, Kim JH, Jung HJ, Kim NH, Kim BK, Song H (2009) Interstitial tissue-specific gene expression in mouse testis by intra-tunica albuguineal injection of recombinant baculovirus. Asian J Androl. 1:342-50.

Ryoki S, Park H, Ohmori Y, Shoji-Tanaka A, Muramatsu T (2001) An integrase facilitates long-lasting foreign gene expression in vivo in mouse spermatogenic cells. J Biosci Bioeng 91:363-367.

Sato M, Gotoh K, Kimura M (1999) Sperm-mediated gene transfer by direct injection of foreign DNA into mouse testis. Transgenics 2:357-369.

Sato M, Ishikawa A, Kimura M (2002). Direct injection of foreign DNA into mouse testis as a possible in vivo gene transfer system via epididymal spermatozoa. Mol Reprod Dev 61:49-56.

Saunders PT (2003) Germ cell-somatic cell interactions during spermatogenesis. Reprod Suppl. 61:91-101.

Schieve LA, Meikle SF, Ferre C, Peterson HB, Jeng G, Wilcox LS (2002) Low and very low birth weight in infants conceived with use of assisted reproductive technology. $\mathrm{N}$ Engl J Med 346:731-737

Sharpe RM, McKinnell C, Kivlin C, Fisher JS (2003) Proliferation and functional maturation of Sertoli cells, and their relevance to disorders of testis function in adulthood. Reproduction 2003;125:769-784.

Shoji M, Chuma S, Yoshida K, Morita T, Nakatsuji N (2005) RNA interference during spermatogenesis in mice. Dev Biol 282:524-534.

Skakkebaek NE, Rajpert-De Meyts E, Main KM (2001) Testicular dysgenesis syndrome: an increasingly common developmental disorder with environmental aspects. Hum Reprod 16:972-978.

Smith KR. Gene therapy: theoretical and bioethical concepts (2003) Arch Med Res 34: 247268.

Staessen C, Camus M, Clasen K, De Vos A, Van Steirteghem A (1999) Conventional in-vitro fertilization versus intracytoplasmic sperm injection in sibling oocytes from couples with tubal infertility and normozoospermic semen. Hum Reprod 14:2474-2479. 
Sutcliffe AG, Taylor B, Saunders K, Thornton S, Lieberman BA, Grudzinskas JG (2001) Outcome in the second year of life after in-vitro fertilisation by intracytoplasmic sperm injection: a UK case-control study. Lancet 357:2080-2084

Takehashi M, Kanatsu-Shinohara M, Inoue K (2007) Adenovirus-mediated gene delivery into mouse spermatogonial stem cells.Proc Natl Acad Sci U S A 2007;104:2596-2601.

Tani H, Limn CK, Yap CC (2003) In vitro and in vivo gene delivery by recombinant baculoviruses. 2003; J Virol 77:9799-9808.

Travis LB, Beard C, Allan JM, Dahl AA, Feldman DR, Oldenburg J, Daugaard G, Kelly JL, Dolan ME, Hannigan R, Constine LS, Oeffinger KC, Okunieff P, Armstrong G, Wiljer D, Miller RC, Gietema JA, van Leeuwen FE, Williams JP, Nichols CR, Einhorn LH, Fossa SD (2010) Testicular cancer survivorship: research strategies and recommendations. J Natl Cancer Inst. 102:1114-30.

Umemoto Y, Sasaki S, Kojima Y (2002) In vivo gene transfer to mouse testis and the influence of mouse spermatogenesis. J Urol 2002;167 (Suppl): 322.

Umemoto Y, Sasaki S, Kojima Y (2005) Gene transfer to mouse testes by electroporation and its influence on spermatogenesis. J Androl . 2005;26:264-271.

Weichselbaum RR, Kufe D. Gene therapy of cancer. Lancet 1997;349:10-12.

Weiss J, Axelrod L, Whitcomb RW, Harris PE, Crowley WF, Jameson JL (1992) Hypogonadism caused by a single amino acid substitution in the beta subunit of luteinizing hormone. N Engl J Med 326:179-183.

Weiss J, Meeks JJ, Hurley L, Raverot G, Frassetto A, Jameson JL (2003) Sox3 is required for gonadal function, but not sex determination, in males and females. Mol Cell Biol 23:8084-8091.

Xu Q, Lin HY, Yeh SD (2007) Infertility with defective spermatogenesis and steroidogenesis in male mice lacking androgen receptor in Leydig cells. Endocrine 32:96-106.

Yamamoto H, Ochiya T, Tamamushi S (2002) HST-1/FGF-4 gene activation induces spermatogenesis and prevents adriamycin-induced testicular toxicity. Oncogene 21:899-908.

Yamazaki Y, Fujimoto H, Ando H, Ohyama T, Hirota Y, Noce T (1998) In vivo gene transfer to mouse spermatogenic cells by deoxyribonucleic acid injection into seminiferous tubules and subsequent electroporation. Biol Reprod 59:1439-1444.

Yamazaki Y, Yagi T, Ozaki T, Imoto K (2000) In vivo gene transfer to mouse spermatogenic cells using green fluorescent protein as a marker. J Exp Zool 286:212-218.

Yang Y, Nunes FA, Berencsi K, Furth EE, Gönczöl E, Wilson JM (1994) Cellular immuninty to viral antigen limits E1-deleted adenoviruses for gene therapy. Proc Natl Acad Sci USA 91: 4407-4411.

Yomogida K, Yagura Y, Nishimune Y (2002) Electroporated transgene-rescued spermatogenesis in infertile mutant mice with a sertoli cell defect.Biol Reprod 67:712-717.

Yonezawa T, Furuhata Y, Hirabayashi K, Suzuki M, Takahashi M, Nishihara M (2001) Detection of transgene in progeny at different developmental stages following testis-mediated gene transfer. Mol Reprod Dev 60:196-201.

Yu RN, Ito M, Saunders TL, Camper SA, Jameson JL (1998) Role of Ahch in gonadal development and gametogenesis. Nat Genet 20:353-357.

Zani M, Lavitrano M, French D, Lulli V, Maione B, Sperandio S, Spadafora C (1995) The mechanism of binding of exogenous DNA to sperm cells: factors controlling the DNA uptake. Exp Cell Res 217:57-64.

Zuniga A, Lawrentschuk N, Jewett MA (2010). Organ-sparing approaches for testicular masses. Nat Rev Urol. 2010;7:454-64. 


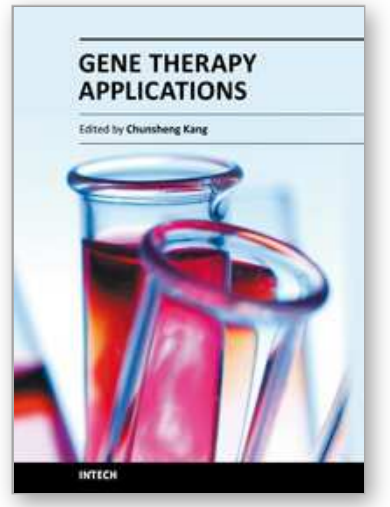

\author{
Gene Therapy Applications \\ Edited by Prof. Chunsheng Kang
}

ISBN 978-953-307-541-9

Hard cover, 492 pages

Publisher InTech

Published online 23, August, 2011

Published in print edition August, 2011

The aim of our book is to provide a detailed discussion of gene therapy application in human diseases. The book brings together major approaches: (1) Gene therapy in blood and vascular system, (2) Gene therapy in orthopedics, (3) Gene therapy in genitourinary system, (4) Gene therapy in other diseases. This source will make clinicians and researchers comfortable with the potential and problems of gene therapy application.

\title{
How to reference
}

In order to correctly reference this scholarly work, feel free to copy and paste the following:

Yoshiyuki Kojima, Kentaro Mizuno, Yukihiro Umemoto, Shoichi Sasaki, Yutaro Hayashi and Kenjiro Kohri (2011). Therapeutic Potential of Gene Transfer to Testis; Myth or Reality?, Gene Therapy Applications, Prof. Chunsheng Kang (Ed.), ISBN: 978-953-307-541-9, InTech, Available from:

http://www.intechopen.com/books/gene-therapy-applications/therapeutic-potential-of-gene-transfer-to-testismyth-or-reality-

\section{INTECH}

open science | open minds

\author{
InTech Europe \\ University Campus STeP Ri \\ Slavka Krautzeka 83/A \\ 51000 Rijeka, Croatia \\ Phone: +385 (51) 770447 \\ Fax: +385 (51) 686166 \\ www.intechopen.com
}

\author{
InTech China \\ Unit 405, Office Block, Hotel Equatorial Shanghai \\ No.65, Yan An Road (West), Shanghai, 200040, China \\ 中国上海市延安西路65号上海国际贵都大饭店办公楼 405 单元 \\ Phone: +86-21-62489820 \\ Fax: $+86-21-62489821$
}


(C) 2011 The Author(s). Licensee IntechOpen. This chapter is distributed under the terms of the Creative Commons Attribution-NonCommercialShareAlike-3.0 License, which permits use, distribution and reproduction for non-commercial purposes, provided the original is properly cited and derivative works building on this content are distributed under the same license. 